The Role of the Principal as a Learning Leader Judging from Permendiknas Number $\mathbf{2 8}$ of $\mathbf{2 0 1 0}$ at SMP IT An-Nisa Dompu

\title{
Peran Kepala Sekolah Sebagai Pemimpin Pembelajaran Ditinjau dari Permendiknas Nomor 28 Tahun 2010 di SMP IT An-Nisa Dompu
}

\author{
Mujiono Sang Putra ${ }^{1}$, Sofyan Syamratulangi ${ }^{2}$, Kamaluddin ${ }^{3}$ \\ doi: https://doi.org/10.51518/lentera.v4i1.64

\begin{abstract}
mujisaputra64@gmail.com syamratulangisofia@gmail.com kamalphysic20@gmail.com
\end{abstract}

Dosen pada STKIP Al-Amin Dompu - Indonesia

\begin{abstract}
This study aims to determine the extent of the principal's role as a learning role at SMP IT An-Nisa Dompu, and to determine the extent of the implementation of Permendiknas No. 28 of 2010 concerning the role of school principals and their position in organizing educational units in schools. The type of research used is a qualitative research method, which is carried out by collecting data in the form of numbers, the data in the form of numbers are then processed and analyzed to obtain scientific information behind these numbers. As a school principal, he must have a leadership spirit and be able to provide guidance and supervision, increase the willingness of educational staff, open two-way communication, and delegate tasks. conducive school organization that fosters the spirit of educators and students. With the leadership of the principal, the principal is expected to be able to provide encouragement and contribute to progress that can inspire the process of achieving its goals. Managerial ability is closely related to how the implementation of management functions or management processes, namely planning, organizing, implementing, controlling, and evaluating related to the role of learning leaders
\end{abstract}

Keywords: Implementation, Permendiknas Number 28 of 2010, the Role of the Principal

\begin{abstract}
Abstrak: Penelitian ini bertujuan untuk mengetahui sejaumana peran kepala sekolah sebagai peran pembelajaran di SMP IT An-Nisa Dompu, serta untuk mengetahui sejauhmana implementasi Permendiknas No 28 Tahun 2010 tentang peran kepala sekolah dan kedudukan dalam penyelengara satuan pendidikan di sekolah. Jenis penelitian yang digunakan adalah metode penelitian kulitatif, yang dilakukan dengan mengumpulkan data yang berupa angka, data yang berupa angka tersebut kemudian diolah dan dianalisis untuk mendapatkan suatu informasi ilmiah di balik angka-angka tersebut. Sebagai seorang kepala
\end{abstract}

73 | Edisi 4 No. 1 Agustus 2021 - Januari 2022 
sekolah harus memiliki jiwa kepemimpinan dan mampu memberikan petunjuk dan pengawasan, meningkatkan kemauan tenaga kependidikan, membuka komunikasi dua arah, dan mendelegasikan tugasUntuk itu kepala sekolah bertangung jawab melaksanakan fungsifungsi kepemimpinan baik yang berhubungan dengan pencapaian tujuan pendidikan maupun dalam menciptakan iklim dalam organisasi sekolah kondusif yang menumbuhkan semangat tenaga pendidik maupun perserta didik. Dengan kepemimpinan kepala sekolah inilah, kepala sekolah diharapkan mampu memberikan dorongan dan kontribusi untuk kemajuan yang dapat memebrikan inspirasi dalam proses pencapaian tujuannya. Pada dasarnya kemampuan manajerial sangat terkait dengan bagaimana penerapan fungsi-fungsi manajemen atau proses manajemen, yaitu perencanaan, pengorganisasian, pelaksanaan, pengontrolan, dan evaluasi yang berkaitan dengan peran dalam pemimpin pembelajaran

Kata kunci: Implementasi, Permendiknas Nomor 28 Tahun 2010, Peran Kepala Sekolah

\section{PENDAHULUAN}

Pendidikan merupakan upaya mencerdaskan kehidupan bangsa dimna maju dan berkembangnya suatu bangsa dilihat dari pendidikannya. Hal ini dapat kita jumpai diberbagai Negara-negara yang maju akan beradaban manusia secara akademik. Reformasi pendidikan melalui pelaksanaan desentralisasi pendidikan dalam rangka otonomi daerah yang telah berjalan beberapa waktu ini telah sangat menentukan sosok dan kinerja sistim pendidikan, terutama sistim pendididikan nasonal dimasa depan. Pendidikan merupakan kebutuhan bagi warga masyarakat untuk bisa menentukan barang dan jasa apa yang diperlukan. Bahkan secara makro, pendidikan merupakan jantung sekaligus tulang punggung masa depan bangsa dan Negara (Zamroni, 2011). Bahkan keberhasilan suatu bangsa sangat ditentukan oleh keberhasilan dalam memperbaiki dan memperbahurui sektir pendidikan (Zian Farodis, 2011). Sedangkan di sisi yang lain, sistim pendidikan merupakan suatu kawah candradimuka pembentuk manusia sempurna sebagai fondasi awal dalam pembangunan peradaban madani. (Sofyan Syamratulangi, 2020)

Seorang kepala Sekolah merupakan salah satu faktor yang terpenting dalam proses pencapaian, keberhasilan sekolah dalam pencapaian tujuannya. Dengan demikian Kepala Sekolah sangat diharapkan pengaruhnya untuk mengendalikan proses pendidikan berjalan sesuai harapan semua pihak. Dalam menjalankan kepemimpinannya kepala sekolah tergantung kepada guru karena guru merupakan ujung tombak pelaksanaan pendidikan (Almilia.dkk, 2007). Pendidikan sebagai aktivitas yang di sengaja untuk mencapai tujuan tertentu dan

\section{4|Edisi 4 No. 1 Agustus 2021 -Januari 2022}


melibatkan berbagai faktor yang saling berkaitan antara satu dan lain nya sehingga membentuk satu sistem yang saling mempengaruhi (Ginanjar, 2015).

Pemimpin adalah orang yang mempunyai anak buah dalam suatu lenbaga. Pemimpin dapat diartikan sebagai pengerak utama dalam suatu lembaga pendidikan yang menjadi pemegang utama jalan nya organisasi, orang yang mempunyai wewenang dalam pengambilan keputusan, dan memiliki kemamapuan mempengaruhi orang lain untuk melaksanakan tugas-tugas tertentu yang menjadi tujuan dan ambisinya, dismaping itu. Pemimpin memiliki kekuasaan, pengaruh, kekutan, dan pemegang tanggung utama bagi seluruh kegiatan yang dilakukan oleh bawahannya. (Rodriguez \& Honeycutt, 2014)

Belajar dapat dipandang sebagai proses yang diarakan pada tujuan dan proses berbuat melalui berbagai pengalaman. Belajar juga merupakan proses melihat, mengamati, dan memahami sesuatu (Walidah, 2017). Proses pembelajaran dilakukan oleh dua pihak, yaitu guru dan peserta didik. Perilaku guru adalah adalah mengajar dan perilaku peserta didik adalah menerima pembalajaran. Pemebelajran merupakan suatu sistim, yang teridri atas berbagai komponen yang saling berhubungan satu dengan yang lain. Komponen tersebut meliputi: tujuan, materi, metode, dan evaluasi. Keempat komponen pembelajaran tersebut harus diperhatikan oleh guru dalam memilih dan menentukan modelmodel pembelajaran apa yang akan digunakan dalam kegiatan (S Syamratulangi, 2019).

Penugasan guru sebagai kepala sekolah/madrasah yang ditinjau dari Permendikas No 28 Tahun 2010 adalah a). bahwa guru dapat diberikan tugas tambahan sebagai kepala sekolah/madrasah untuk memimpin dan mengelola sekolah/madrasah dalam upaya meningkatkan mutu pendidikan; b). bahwa dalam rangka meningkatkan kualitas kepala sekolah/madrasah perlu dilakukan pendidikan dan pelatihan calon kepala sekolah/madrasah serta sertifikasi kompetensi dan penilaian kinerja kepala sekolah/madrasah; c). bahwa Keputusan Menteri Pendidikan Nasional Nomor 162/U/2003 tentang Pedoman Penugasan Guru sebagai Kepala Sekolah sudah tidak sesuai dengan perkembangan sistem pendidikan nasional; dan d). bahwa berdasarkan pertimbangan sebagaimana dimaksud pada huruf a, b, dan c perlu menetapkan Peraturan Menteri Pendidikan Nasional tentang Penugasan Guru Sebagai Kepala Sekolah/Madrasah;

Peran kepemimpinan kepala sekolah berkaitan dengan berbagai tugas dan fungsi yang harus di jalankan dalam mewujudkan sekolah efektif, produktif, mandiri, dan akuntabel, dari berbagai tugas dan fungsi seorang kepala sekolah yang harus diembannya dalam mengembangkan sekolah secara efektif, efesien, produktif dan akuntabel tersebut. Sedikitnya terdapat sepuluh kunci kepemimpinannya. Yang mencangkup visi yang utuh. Tanggung jawab, keteladanan, memberikan layanan terbaik. Mengembangkan orang, membina rasa keastuan dan persatuan, focus pada peserta didik, manajemen yang mengutamakan praktik, menyesuaikan gaya kepemimpinan, dan memanfaatkan kekuasaan keahlian. (Mulyasa. 2012:102). 
Kepemimpinan pendidikan berkaitan dengan masalah kepala sekolah dalam meningkatkan kesempatan untuk mengadakan pertemuan secara efektif denagan para guru dalam situasi yang kondusif. Tugas dan fungsi seorang kepala sekolah harus dapat mendorong kinerja para guru dengan menunjukan rasa bersahabat, dekat, dan penuh pertimbangan terhadap para guru, baik sebagai individu maupun sebagai kelompok. Perilaku instrumental kepala sekolah merupakan tugas-tugas yang diorentasikan dan secara langsung diklarifikasikan dalam peranan dan tugas-tugas para guru, sebagai individu dan sebagai kelompok. Perilaku kepala sekolah yang positif dapat mendorong, mengarahkan, dan memotivasi seluruh warga sekolah untuk bekerja sama dalam mewujudkan visi, misi, dan tujauan sekolah (Mulyasa. 2012:93).

Kepala sekolah sebagai leader harus harus mampu memberikan petunjuk dan pengawasan, menigkatkan kemauan tenaga kependidikan, membuka komunikasi dua arah, dan mendelegasikan tuagas (Wahjosumijo 1993; Mulyasa, 2012:108). Mengemukakan bahwa kepala sekolah sebagai leadaer harus memiliki karakter khusus yang mencangkup kepribadian, keahlian dasar, pengalaman, dan pengetahuan professional, serta pengetahuan administrasi dan pengawasan.

Gaya kepemimpinan seorang kepala sekolah adalah pola tindakan pemimpin secara keseluruhan seperti yang dipersepsikan oleh para pegawainya. Hasil penelitian Miller Etal (1991) menyimpulkan bahwa terdapat hubungan/pengaruh signifikan antara gaya kepemimpinan dengan kepuasan kerja. Menurut pendapat Gruenberg (1980) diperoleh bahwa hubungan yang akrab dan saling tolong-menolong dengan teman sekerja serta penyelia adalah sangat penting dan memiliki hubungan yang kuat dengan kepuasan kerja dan tidak ada kaitannya dengan keadaan tempat kerja serta jenis pekerjaan. Kepemimpinan sebagai istilah umum dapat dirumuskan sebagai proses dengan sengaja mempengaruhi orang lain dalam merealisasikan tujuan. Nawawi melihat kepemimpinan sebagai proses mengarahkan, membimbing, mempengaruhi atau mengawasi pikiran, perasaan atau tindakan. (Hadari Nawawi, 1985) Kepemimpinan dalam kontek sekolah lebih menekankan pada terjadinya hubungan antara personil sekolah serta menciptakan iklim kebersamaan dan saling memiliki yang ditandai dengan rasa kebersamaan dalam bekerja. Dalam kondisi seperti itu akan tercipta hubungan yang harmonis diantara seluruh personil sekolah (Kepala Sekolah, Guru, Staf Tata Usaha, Siswa, masyarakat, dII). Sebagai pemimpin formal, kepala sekolah bertanggung jawab atas tercapainya tujuan pendidikan melalui upaya menggerakkan bawahan ke arah pencapaian tujuan pendidikan yang telah ditetapkan. Dalam hal ini kepala sekolah bertugas melaksanakan fungsi-fungsi kepemimpinan, baik fungsi yang berhubungan dengan pencapaian tujuan pendidikan maupun penciptaan iklim sekolah yang kondusif bagi terlaksananya proses belajar mengajar secara efektif dan efisien. (Djumadi, P 2011:17)

Kepala sekolah sebagai pengelola dan eksekutif disekolah menunjukan dirinya sebagai seorang pelaksana teknis manajerial yang memilki keterampilan untuk menjalankan sekolah. Kepala sekolah sebagai manejer bertugas sebagai

76| Edisi 4 No. 1 Agustus 2021 - Januari 2022 
pelaksana kurikulum, pengatur personil, fasilitas, keuangan, ketatausahaan sekolah, pemelihara tata tertib serta hubungan sekolah dan masyarakat. Pembangunan, perkembangan ilmu dan teknologi selalu berubah, oleh karena itu sekolah perlu mengikuti pekembangan ilmu dan teknologi. Kepala sekolah dalam kepemimpinan memerlukan pengetahuan dan keterampilan konseptual, kemampuan untuk melihat organisasi secara keseluruhan yang termasuk kesanggupan untuk melihat dengan jelas peranan organisasi dalam situasi pembangunan yang menyeluruh. (Rohiat 2010:86).

Berkaitan dengan kepemimpinan kepala sekolah sebagai seorang pemimpin dalam pembelajaran yang di lingkungan sekolah dalam rangka mewujudkan tujauannya kegiatan pembelajaran, sehingga seluruh aktivitas organisasi sekolah bermuara pada pencapaian efesiensi dan efektivitas pembelajaran. Oleh karena itu, salah satu tugas kepala sekolah adalah sebagai supervisior,yaitu mensupervisi pekerjaan yang dilakukan oleh tenaga kependidikan. Sergiovani dan Starat (Mulyasa 2012:109).

Model kepemimpinan ada sembilan yaitu: 1) manajerial; 2) partisipatif; 3) transformasional; 4) interpersonal; 5) transaksional; 6) postmodern; 7) kontingensi; 8) moral; dan 9) pembelajaran (intruksional). kepemimpinan pembelajaran karena: relevan dengan bidang keahlian peneliti, komponen paling penting dalam meningkatkan mutu pembelajaran, faktor penting yang menentukan keefektifan sekolah (Huber, 2010), mengantisipasi tuntutan kompetensi kepala sekolah abad 21, mendukung keberhasilan implementasi Kurikulum 2013, kepemimpinan sekolah paling sukses jika difokuskan pada pembelajaran Leihwood \& Riehl (2008 \& Gurr; Drysdale, 2008), dan sukses atau gagalnya sekolah mencapai tujuan ditentukan oleh kepemimpinan kepala sekolahnya (Hoy \& Miskel, 2008; Bass \& Bass \& Huber,2010).

Konsep kepemimpinan pembelajaran memiliki sejarah yang panjang, kompleks, dan multi interpretasi tentang segala sesuatu yang harus dilakukan kepala sekolah Gurr \& Drysdale (2018). Pada tahun 1960, para kepala sekolah meningkatkan mutu pembelajaran dengan melakukan observasi ke kelas-kelas. Pada 1970 ketika Amerika Utara, Inggris, dan Australia menerapkan sistem inspeksi terhadap pembelajaran, peranan kepala sekolah sangat ditekankan. Pada tahun 1970-an sampai awal 1980-an, buku teks administrasi pendidikan difokuskan pada supervisi. Beberapa literatur mengungkapkan bahwa supervisi dapat meningkatkan mutu pembelajaran di kelas.Kepala sekolah adalah orang yang paling bertanggung jawab terhadap kepemimpinan pembelajaran dan pengembangan kurikulum (Gurr \& Drysdale 2018:11). Sejak tahun 1970 definisi kepemimpinan pembelajaran masih membingungkan. Kepemimpinan pembelajaran mencapai puncaknya di Amerika Utara pada tahun 1980 dan fokus kepemimpinan pada peran kepala sekolah dalam kepemimpinan pembelajaran (Wartomo, 2016)

Kata kinerja yang berarti menampilkan atau melaksanakan prestasi kerja, pelaksanaan kerja, pencapaian kerja, atau penampilan kerja. Gunawan (2015), kinerja adalah sesuatu yang dicapai, prestasi yang diperlihatkan, atau

$$
\text { 77|Edisi 4 No.1 Agustus } 2021 \text {-Januari } 2022
$$


kemamapuan kerja, pendapat para ahli mengenai kinerja cukup beragam. Menurut Aritonang (2005), kinerja adalah hasil kerja secara kualitas dan kuantitas yang dicapai oleh seorang pegawai dalam melaksanakan tugasnya sesuai dengan tanggung jawab yang di berikan padanya.

Kepemimpinan sebagai salah satu fungsi manajemen merupakan hal yang sangat penting untuk mencapai tujuan organisasi, dalam hal ini kepemimpinan dapat berperan di dalam melindungi beberapa isu pengaturan organisasi yang tepat, seperti: distribusi kekuasaan yang menjadi penghalang tindakan yang efektif, kekurangan berbagai macam sumber, prosedur yang dianggap buruk (archaic procedure), dan sebagainya yaitu problem-problem yang lebih sifat mendasar. Wahjosumidjo. (2004:63). Kerja sama yang di bangun oleh sifat-sifat kepemimpinan didasarkan pada wewenangnya yang diatur oleh norna-norma yang berlaku. Pengaruh kepemimpinan akan mengerakkan seluruh anak buahnya bekerja secara interelatif dan sinergis sehingga dapat dicapai dengan cara efektif dan efesien.

Kepemimpinan kepala sekolah dalam peningkatan kualitas pendidikan tidak lepas dari perilaku pemimpin yang diciptakan yaitu paternelistik, kepatuhankepatuhan semu, kemandirian dalam bekerja lemah, konsensus, dan menghindar. Gaffar (Mulyasa 2012:53). Perilaku paternelistik dalam kepemimpinan munculkan sikap bawahan. Keengganan bawahan untuk mengungkapkan pikiran, pendapat dan kritik terhadap atasan karena khawatir dianggap menetang atasan, dominasi atasan terhadap bawahan sangat kuat, sehingga bila muncul gagasan pembaharuan dari bawahan seringkali diangaap sebagai tantangan terhadap kebijakan pemimpin. (Engkoswara 2001:84).

Kegiatan utama pendidikan di sekolah dalam rangka mewujudkan tujuannya adalah kegiatan pembelajaran, sehingga seluruh aktivitas organisasi sekolah bermuara pada pencapaian efisiensi dan efektivitas pembeljaran. Oleh karena itu salah satu tugas kepala sekolah adalah sebagai supervisior, yaitu mempervisi pekerjaan yang dilakukan oleh tenaga kependidikan. Sergiovani dan Starrtat (2001); Mulyasa ( 2012).

Strategi kepemimpinan pembelajaran yang ditemukan Southworth (2002) dalam penelitian dengan pendekatan kualitatifnya pada Kepala Sekolah Dasar di Inggris dan Wales ada tiga strategi untuk meningkatkan pembelajaran secara efektif yaitu: (1) modeling; (2) monitoring, dan (3) professional dialog and discussion. Modelling artinya keteladanan kepala sekolah menjadi contoh atau model yang ditiru oleh guru di sekolah yang dipimpinnya. Monitoring artinya melakukan pemantauan kinerja guru ke kelas saat guru melaksanakan proses pembelajaran di kelas serta memanfaatkan hasil pemantauan tersebut untuk pembinaan lebih lanjut. Professional dialog and discussion artinya berarti membicarakan secara aktif, interaktif, efektif, aspiratif, inspiratif, produktif, demokratik dan ilmiah tentang hasil penilaian kinerja dan rencana tindak lanjut peningkatan mutu proses dan hasil pembelajaran siswa.(Rusman dan Eko 2013;3).

78| Edisi 4 No.1 Agustus 2021 -Januari 2022 
Mengingat tugas Kepala sekolah yang merupakan pemimpin tingkat satuan pendidikan yang harus memiliki dasar kepemimpinan yang kuat. Kepemimpinan pendidikan berkaitan dengan masalah kepala sekolah dalam meningkatkan kinerja kepemimpinan kepala sekolah merupakan upaya yang dilakukan dan hasil yang dapat dicapai oleh kepala sekolah dalam mengimplementasikan manajemen sekolah untuk mewujdkan tujaun pendidikan secara efktif dan efesien, produktif, dan akuntabel (Mulyasa, 2012). Dengan demikaian maka permasalahan yang dikemukakan adalah maka dalam penulisan ini akan dikaji bagaimana landasan Permendiknas No. 28 Tahun 2010 tentang penugasan guru sebagai kepala sekolah di SMP IT An-Nisa Dompu? Bagaimana peran kepala sekolah dalam rancangan pembelajaran di SMP IT An-Nisa Dompu?

Penelitian yang penulis laksanakan untuk mencari, mengumpulkan, dan memperoleh data yang dapat memberikan informasi dan gambaran berkaitan dengan impelementasi Permendinas No. 28 Tahun 2010. Tujuan penelitian yaitu untuk mengetahui sejaumana peran kepala sekolah sebagai peran pembelajaran di SMP IT An-Nisa Dompu, serta untuk mengetahui sejauhmana implementasi PERMENDIKNAS No 28 Tahun 2010 tentang peran kepala sekolah dan kedudukan dalam penyelengara satuan pendidikan di sekolah.

\section{METODE}

Penelitian ini menggunakan pendekatan penelitian kualitatif. penelitian yang ditunjukan untuk mendiskripsikan dan menganalisa fenomena, peristiwa, aktifitas sosial, sikap, kepercayaan, persepsi, pemikiran orang secara individual maupun kelompok. Jenis penelitian yang digunakan adalah jenis penelitian diskriptif yaitu bentuk penelitian yang menggambarkan fenomena-fenomena yang ada berdasarkan kondisi apa adanya. Penelitian deskriptif pada umumnya dilakukan dengan tujuan utama yaitu menggambarkan secara sistematis fakta dan karakteristik obyek atau subyek yang diteliti secara tepat (Sukardi, 2003: 157 dalam Muliati, 2010:34)

Lokasi penelitian ini di SMP IT An-Nisa Dompu. Sedangkan waktu dalam penelitian ini disesuaikan dengan jadwal pada SMP IT An-Nisa Dompu yang dilakukan pada semester ganjil tahun ajaran 2020-2021. Penelitian ini menggunakan teknik pengumpulan data dengan cara wawancara, observasi, angket dan studi dokumen. Menurut Moelong (2000: 168 dalam Mulyati, 2010: 35) menjelaskan bahwa teknik dalam pengumpulan data dalam penelitian kualitatif mempersyaratkan kehadiran peneliti di lokasi penelitian. Peneliti berperan sebagai perencana, pengumpul data, analisis dan penafsir data, serta sebagai pelapor hasil penelitianya. Kehadiran peneliti di lokasi penelitian berperan sebagai key instrument. Teknik pengumpulan data dilakukan sebagai berikut: Analisis data dilakukan sejak awal turun ke lokasi penelitian dengan pengumpulan data melalui cara mengangsur atau menabung informasi, mereduksi, mengelompokan dan memberi interpretasi. Makna data merupakan deskripsi dari pertanyaan-pertanyaan seseorang tentang perspektif, pengalaman, sikap, 
keyakinan dan pikiranya serta petikan isi dokumen yang berkaitan dengan peran kepala sekolah sebagai pemimpin pembelajaran.

\section{HASIL DAN PEMBAHASAN}

Hasil dari penelitian ini merupakan salah satu kondisi nyata yang ada di sekolah tempat berlangsung nya pemgambilan data dan sekaligus tempat penelitian. Salah satu aspek penting dari ketujuh Komponen kepala sekolah sebagai educator adalah pelaksana tugas mengajar di dalam kelas demikian pula kepala SMP IT An Nisa Dompu, dalam melaksanakan tugas kepemimpinan dan manajerianya sebagai oemimpin dan juga dituntut untuk tetap melaksanakan tugas akademiknya yaitu mengajar sebanyak enam jam pelajaran perminggu. Masalah yang muncul adalah pembagian waktu antara melaksanakan tugas sebagai kepala sekolah dan tugas akademik sebagai seorang pendidik. Demikian pula kepala SMP IT An-Nisa Dompu, selain melaksanakan tugas kepemimpinan dan manajerial sebagai kepala sekolah, dituntut pula untuk tetap melaksanakan tugas akademiknya yaitu mengajar sebanyak 6 jam pelajaran per minggu. Masalah yang muncul adalah pembagian waktu antara melaksanakan tugas sebagai kepala sekolah dan melaksanakan tugas akademiknya yaitu mengajar 6 jam pelajaran per minggu. Kepala sekolah SMP IT An-Nisa Dompu mengajar 6 jam pelajaran per minggu untuk mata pelajaran matematika. Memang harus diakui bahwa seringkali kepala sekolah meninggalkan tugas mengajar karena harus melaksanakan tugas sebagai kepala sekolah, misalnya ada rapat di Dinas Pendidikan yang waktunya bertepatan dengan jadwal mengajar. Oleh sebab itu, kepala sekolah melakukan upaya dengan menyusun jam mengajar untuk saya pada hari Jum'at dan sabtu.

Pertimbangannya karena kegiatan di dinas Pendidikan untuk hari Jum'at setengah hari dan pada hari Sabtu kantor tutup, sehingga pada hari Jum'at dan Sabtu dapat melaksanakan tugas mengajar secara penuh. Adanya upaya kepala sekolah untuk menyusun jadwal mengajar pada hari Jum'at dan Sabtu merupakan langkah yang menurut penulis tepat karena pada hari Jum'at biasanya kegiatan di kantor Dinas Pendidikan tidak terlalu padat dan pada hari Sabtu kantor libur. Selain itu, adanya aturan jam menerima tamu menunjukkan bahwa kepala sekolah cukup baik dalam mengelola waktu melaksanakan tugas akademik dan tugas sebagai kepala sekolah.

Kepala sekolah sebagai leader harus mampu memberikan petunjuk dan pengawasan, meningkatkan kemauan tenaga kependidikan, membuka komunikasi dua arah, dan mendelegasikan tugas. Wahjosumijo (2010:101) mengemukakan bahwa kepala sekolah sebagai leader harus memiliki karakter khusus yang mencakup kepribadian, keahlian dasar, pengalaman dan keahlian-profesional, serta pengetahuan administrasi dan pengawasan.

Pengelolaan sekolah, peran kepala sekolah sangat menonjol, bukti bahwa peran tersebut sangat kuat, keberadaan kepala sekolah yang baik, sangat besar sumbangannya terhadap sekolah. Mulyasa (2006:25) mengatakan bahwa kepala

$$
\text { 80| Edisi } 4 \text { No. } 1 \text { Agustus } 2021 \text {-Januari } 2022
$$


sekolah harus memiliki strategi yang tepat untuk meningkatkan profesionalisme tenaga kependidikan di sekolahnya, menciptakan iklim sekolah yang kondusif, dan memberi nasehat kepada warga sekolah. Kepala sekolah sebagai manajer pendidikan harus bertanggung jawab sepenuhnya terhadap kelancaran pelaksanaan pendidikan dan pembelajaran di sekolah. Oleh karena itu kepala sekolah mempunyai peranan penting dan tanggungjawab yang berat, sehingga memerlukan suatu kecakapan yang tinggi dalam berbagai bidang terutama pada profesi yang diembannya selaku manajer dalam pelaksanaan proses pembelajaran di sekolah.

\section{KESIMPULAN}

Melihat hasil penelitian yang di paparkan dalam penelitian ini bahwa peran kepala sekolah sebagai pemimpin pembelajaran tidak mengalami hambatan dan kesulitan apapun, hal ini dapat dilihat dari pembagian waktu mengajar kepala sekolah dalam memanajemen sekolah. Pengelolaan tugas kepala sekolah sebagai guru di SMP IT An-Nisa Dompu telah dilaksanakan dengan baik terutama dalam mengelola waktu untuk melaksanakan tugas akademik sebagai guru adalah dengan pemilihan hari mengajar yang dianggap tidak terlalu banyak kegiatan kepala sekolah yang berhubungan dengan Dinas Pendidikan yaitu pada hari Jum'at dan Sabtu. Pengelolaan tugas kepala sekolah sebagai pemimpin yang dilakukan oleh kepala sekolah meliputi transformasi Visi dan Misi serta tujuan sekolah, penyusunan perencanan sekolah dilaksanakan dengan baik yang didukung adanya pemahaman seluruh warga sekolah akan Visi, Misi dan tujuan sekolah tersebut, serta perencanaan sekolah. Selain itu, pelaksanaan tugas pengelolaan sumber daya sekolah yang dilakukan oleh kepala sekolah. 


\section{DAFTAR RUJUKAN}

Al Walidah, I. (2017). Tabayyun di era generasi millenial. Jurnal Living Hadis, 2(2), 317-344.

Almilia, L. S., \& Wijayanto, D. (2007, November). Pengaruh environmental performance dan environmental disclosure terhadap economic performance. In Proceedings The 1st Accounting Conference (Vol. 1).

Anders, S., \& Huber, W. (2010). Differential expression analysis for sequence count data. Nature Precedings, 1-1.

Aritonang, Keke. T., 2005. Kompensasi Kerja, Disiplin Kerja Guru Dan Kinerja Gutu SMP Kristen BPK PENABUR.Jurnal Pendidikan Penabur. No 4. Th IV. Jakarta.

Bass, M. \& Bass, R. (2008). The Bass Handbook of Leadership Theory, Research, \& Managerial Applications. Fourth Edition. New York: Free Press.

Djumadi, P \& Sunarto (2011). Pengaruh Gaya Kepemimpinan Kepala Sekolah, Manajemen Berbasis Sekolah (Mbs) Dan Iklim Organisasi Terhadap Kepuasan Kerja Dan Kinerja Guru Smp Di Wilayah Sub Rayon 04 Kabupaten Demak. Analisis ManajemenVol.5 No.1

Engkoswara. 2001. Paradigma Manajemen Pendidikan. Menyongsong Otonomi Daerah. Bandung. Yayasan Amal Keluarga

Farodis, Zian. (2011). Panduan manajemen pendidikan ala Harverd University / Zian Farodis . Yogyakarta: Diva Press.

Ginanjar, A. (2015). The Influence of Inquiry Method in Motivating the SMP'Students. Jurnal Kependidikan: Penelitian Inovasi Pembelajaran, 45(2).

Gruenberg, B. (1980). The happy worker: An analysis of educational and occupational differences in determinants of job satisfaction. American journal of sociology, 86(2), 247-271.

Gunawan, I. (2015). Strategi meningkatkan kinerja guru: apa program yang ditawarkan oleh kepala sekolah. In Prosiding Seminar Nasional Pengembangan Karir Tenaga Pendidik Berbasis Karya Ilmiah, Fakultas Ilmu Pendidikan Universitas Negeri Malang (Vol. 23, pp. 305-312).

Gurr, D., \&Drysdale, L. (2008). Instructional Leadership in Three Australian Schools.

Miller, D. R., Martineau, R. J., Wynands, J. E., \& Hill, J. (1991). Bolus administration of esmolol for controlling the haemodynamic response to tracheal intubation: the Canadian Multicentre Trial. Canadian journal of anaesthesia, 38(7), 849-858.

Muliati.(2010). Kepemimpinan Kepala Sekolah yang Efektif. Jakarta: Bumi Aksara

Mulyasa, E. 2012. Menjadi Kepala Sekolah Profesional. Bandung: Remaja Rosdakarya

Mulyasa. (2006). Menjadi Guru Profesional Menciptakan Pembelajaran Kreatif dan Menyenangkan. Bandung: Penerbit PT Remaja Rosdakarya. 
Nawawi, Hadari. 1985. Organisasi Sekolah Dan Pengelolaan Kelas. Jakarta: Gunung Agung

Permendiknas Nomor 28 Tahun 2010 Tentang Penugasan Guru Sebagai Kepala Sekolah/Madrasah.

Rodriguez, M., Ajjan, H., \& Honeycutt, E. (2014). Using technology to engage and improve millennial students' presentation performance. Atlantic Marketing Journal, 3(2), 3.

Rohiat.(2009). Manajemen Sekolah, Teori Dasar dan Praktik. Bandung: Refika Aditama

Rusman, R., \& Rohman, A. (2017). Development of Training Curriculum in Improving Community-Based Geological Hazard Mitigation Competency. Mimbar: Jurnal Sosial dan Pembangunan, 33(2), 416-425.

Southworth, G. (2002). Instructional leadership in schools: Reflections and empirical evidence. School Leadership \& Management, 22(1), 73-91.

Syamratulangi, S., \& Putra, I. S. (2020). Analisis Kebijakan Diklat Berjenjang Pendamping Guru Muda Pada Kualifikasi Akademik Guru Paud. NUANSA, 8(2), 48-53.

Syamratulangi, S., \& Tinus, A. (2019). Analisis Tingkat Ketercapaian Kompetensi Pedagogi Dan Profesional Guru SMP Negeri 1 Hu'u Dompu. Jurnal Kebijakan dan Pengembangan Pendidikan, 7(1).

Wahjohsumidjo. (2011). Kepemimpinan Kepala Sekolah. Jakarta: Rajawali Press

Wahjosumidjo (2005). Kepemimpinan Kepala Sekolah, Tinjauan Teori dan Permasalahannya. Jakarta: Raja Grafindo Persada.

Wartomo, W. (2016). Peran guru dalam pembelajaran era digital. Prosiding temu ilmiah nasional guru (TING) VIII, 265-275.

Zamroni, 2007, Pendidikan dan demokrasi dalam transisi, Jakarta: PSAP Muhammadiyah. 
ISSN Cetak: 2685-5542

ISSN Online: 2685-5550 